\title{
Serum Lactate Dehydrogenase Measurement
}

National Cancer Institute

\section{Source}

National Cancer Institute. Serum Lactate Dehydrogenase Measurement. NCI Thesaurus.

Code C61026.

A quantitative measurement of the amount of lactate dehydrogenase present in a sample of serum. 